\title{
The role of self-congruity in the retail store patronage model: The case of Islamic retail stores in Indonesia and Malaysia
}

\author{
Hendy Mustiko Aji \\ Department of Management, Universitas Islam Indonesia, \\ Indonesia \\ bm.aji@uii.ac.id \\ ORCID 0000-0002-4638-4180 \\ Maizaitulaidawati Md Husin \\ Azman Hashim International Business School, \\ Universiti Teknologi Malaysia \\ maizaitulaidawati@ibs.utm.my \\ ORCID 0000-0002-2789-8274 \\ Muafi Muafi \\ Department of Management, Universitas Islam Indonesia, \\ Indonesia \\ muafi@uii.ac.id (corresponding author) \\ ORCID0000-0002-5078-4670
}

Abstract. Retail industry contributes significantly to national economies. Currently, Islamic retail stores become another phenomenon in Indonesia and Malaysia. Previous studies investigated Muslim customers' preferences to patronage Islamic retail stores rather than conventional ones. Therefore, the purpose of this paper is twofold: to test and validate Islamic retail patronage behavior framework and to compare Islamic retail patronage among the customers between Indonesia and Malaysia. 302 retail customers in Indonesia and 308 retail customers in Malaysia were selected, the purposive $8330.2020 / 13-2 / 5$ 
and recommendations for future research have been provided.

Keywords: retail store, self-congruity, retail patronage, Indonesia, Malaysia.

JEL Classification: L81, F14

\section{INTRODUCTION}

The contribution of retail industry to national economy is not to be questioned. In Malaysia, the retail industry contributed RM 46.9 billion to Malaysia's GDP back in 2012. It also provided more than 500,000 jobs in Malaysia in 2009 (Hashim, Hussin \& Zainal, 2014). Similarly, in Indonesia, the Indonesia Minister of Trade, Enggar Lukita confirmed that retail industry has an imperative contribution to national economy in terms of monetary value as well as in employment opportunities (KEMENDAG, 2017). The retail business in Indonesia is progressing, as proved by a 10\% growth in sales recorded by the year 2016 (Kompas, 2016). In short, retail business has many prospects in Indonesia.

In consumer research literature, the discussion regarding retail marketing usually involves several variables, including store atmosphere (Milliman, 1986; Turley \& Milliman, 2000; Hussain \& Ali, 2015), retail image (Pettijohn, Mellott \& Pettijohn, 1992), brand (Sheau-Fan, Sun-May \& Yu-Ghee, 2012) and patronage (Milliman, 1986; Sirgy, Grewal \& Mangleburg, 2000; Pan \& Zinkhan, 2006).

Based on the key attributes, retail stores in many Asian can be classified into conventional and Islamic. The difference between them can be highlighted in the way the stores serve their shoppers. For instance, conventional retail stores do not pay special attention to Muslim needs in food and to halal labeling. As a consequence, there is no clear distinction between halal and non-halal products sold. In the end, this might create confusion and halal risks. One case happened recently in Indonesia: the Food and Drug Monitoring Agency (BPOM) in Indonesia got proves that Korean instant noodles in several conventional retail stores were not free from pork ingredients (The Jakarta Post, 2017). In Islamic retail stores, Muslim specific needs in food are firmly and carefully served.

The integrative model of retail patronage comprising retail environment and self-congruity has been introduced by Sirgy et al. (2000). They also mentioned several variables that potentially mediate or moderate the patronage intention. According to their model, self-congruity and retail patronage are mediated by self-concept. Besides, variables such as knowledge, prior experience, involvement and time pressure were treated as the moderating ones.

Pan and Zinkhan (2006) in their meta-analysis also highlighted some antecedents of retail patronage behavior. They categorized several variables from previous studies and comprised them into three factors: a) product-relevant, b) market-relevant, and c) personal-relevant factors. Some other variables such as price, quality of products and product selection are considered as the product-relevant factors that might influence retail patronage behavior. However, market-relevant factors are also important such as parking facilities, location, opening hours, friendliness during sales, service, fast checkout, atmosphere, and store image. The retail patronage behavior is assumed to be completely influenced by personal-relevant factors such as gender, age, income, and store-type attribute.

Sirgy et al.'s (2000) and Pan and Zinkhan's (2006) conceptual studies have also been empirically tested by some researchers. Sung and Huddleston (2017) found that self-image congruence is affecting high and low-end retail store patronage. Knoferle, Spangenberg and Herrmann (2012) in their experimental study found that retail store atmosphera, such as music and mode, has impact on in-store 
actual sales. Both studies lend support for Sirgy et al.'s (2000) and Pan and Zinkhan's (2006) conceptual models.

However, the above research missed one important factor in the model — the religious attribute value. Mokhlis (2019) stated that it may form individual behavior, including purchase decisions on what, where, when and even how to purchase. Those commitments are driven by a religious value system (Alhyari, Alnsour \& Al-weshah, 2012). The level of religiosity might also be the cause (Aji, 2017). Concerning it, in the context of 'where' to purchase, it is believed that Muslims are reconsidering to purchase at the retail stores that potentially infringing their belief system. Retail stores can be considered as infringing Islamic values, for example, by the products they sell, the price they charge and also the promotion they use. Together these factors can create a bad image that will possibly negatively impact Muslim retail patronage intention.

As found by Hussin and Zainal (2014), Muslim customers believe that retailers must have specific value attributes to be Islamic. It was also found by Fauzi et al. (2016) that Malaysian Muslim consumers patronizing Islamic retail stores are expecting an Islamic retail store to a) sell Muslim products, b) has Islamic atmosphere, c) be humanistic, d) have halal certification for all products, e) have Islamic values.

It is interesting that in Indonesia and Malaysia conventional retail stores are more widely spread as compared to Islamic ones, even though both these countries are Muslim. This issue becomes the main motive for this paper. What variables are mainly influencing Muslim customers in Indonesia and Malaysia when they decide to patronize Islamic retail stores? Do Muslim customers patronize Islamic retail stores because of the market-relevant factors such as store atmosphere? Or because of the product-relevant factors such as availability of halal products? Or because of the personal-relevant factors such as selfcongruity? Therefore, this paper contributes to literature by examining the Islamic retail patronage model. Moreover, the paper compares the differences between Indonesia and Malaysia Muslim customers in this regard.

\section{LITERATURE REVIEW}

\subsection{Islamic retail store}

The difference between Islamic and conventional retail store is on the value attached. To avoid any confusion, the term Islamic must be differentiated from Islam, Sharia, and Halal. Three of them are often used interchangeably. Aji (2019) explained that three of the terminologies are interrelated. 'Islam' can simply be defined as a religion. Islam as the religion is then derived into rules and regulation, which is termed as Sharia. Any activities in which the operation following the rules and regulations in Islam can be labeled as halal. Therefore, halal is seen as the operationalization of Sharia. Halal in this regard brings a universal value. Anything halal does not always mean Islamic, vice versa. Battour and Ismail (2016) and Douglas and Shaikh (2004) said that the word 'Islamic' is closely related to faith and its doctrine. Accordingly, Islamic has an attributive function.

In the literature, Fauzi et al (2016) found that Malaysian customers expected the Islamic retail stores to a) sell the Muslim products, b) have Islamic atmosphere, c) humanistic, d) halal certification for all products, e) has Islamic values. Hussin and Zainal (2014) from their research found that Muslim respondents believed that Islamic retailers must have specific value attributes to be Islamic. When defined, the Islamic retail store is a retail store with the Islamic attribute concerning the product, market and personal.

As an example, in Malaysia, there are Hijrah Halal Mart and also Halal Mall in the Lembah Klang area. Both of them are Islamic retail stores because the store names clearly show the Islamic attribute. 
Similarly, in Indonesia, there are D'Halal Mart in Yogyakarta province, in which its' name also clearly show Islamic attribute. Moreover, Hijrah Halal Mart, Halal Mall, and D'Halal Mart offer only halal products, the operation following Islamic worship hour, and the woman employees wear hijab. Those are Islamic attributes.

Eventhough Fauzi et al (2016) mentioned 'humanistic' as one of the must-have value that is expected from the Islamic retail store, however, it does not mean that conventional retail store does not have it. Fauzi et al (2016) defined 'humanistic' as a person that has a strong interest in human welfare, values, and dignity. In this regard, retailers with high humanistic values would stress the importance of in-store interaction between salespersons and customers. Therefore, humanistic is a universal value that is not only a value of the Islamic retail store but also the conventional ones. A conventional retail store might not bring the Islamic attribute, but it might also offer halal value in its store operational. Halal does not necessarily mean Islamic. Halal means allowed by sharia, while Islamic is strongly connected to mo'minoon (Islamic person) not Muslim (person who was born Muslim) (Battour \& Ismail, 2016). Simlilarly, Douglass \& Shaikh (2004) also added by stating that Islamic is strongly connected with faith and doctrine. Thus, something that is halal does not necessarily have Islamic attributes.

\subsection{Current retail practice in Indonesia}

It is mentioned that retail plays a significant contribution to the national economy. It is also mentioned that the retail business is forecast to grow. Clearly, those facts show that customers are likely to shop at retail markets.

In Indonesia, retail stores, especially those which sell foods and beverages vary. Named big retail conventional store players such as Hypermart, Giant, and Carrefour. There are also several small-tomedium retail conventional stores such as Indomaret, Alfamart, Alfamidi, Circle-K and so forth. However, the existence of those big and small-to-medium retail conventional stores still do not satisfy Muslim consumers yet. Especially with the concern of the halalness of the products.

There was a relatively newest case in Indonesia regarding Korean instant noodles, branded Samyang, Nongshim and Ottogi (The Jakarta Post, 2017). Those are the instant noodles containing pork, yet available in many retail stores in Indonesia. The Food and Drug Monitoring Agency (BPOM) in Indonesia pulled them from the market to stop and avoid any problems. The question is, why Indonesia Muslim customers willing to buy those Korean-originate instant noodles which are not halal certified? Many factors to be tested, but, it is believed that conventional retail stores created this problem since they did not separate halal from haram products.

Muslims want and expect to acquire foods and services according to their religious tenets, thus, the requirement for sharia compliance has become more prevalent (Abu Bakar \& Hussin, 2013). This need is responded by the retail industry by the emergence of several sharia-based retail stores. At the regional level, there is 'Tip-Top Supermarket' in Jakarta, 'Pamela Supermarket' and 'D'halal Mart' in Yogyakarta. Evoked by the December 2nd biggest demonstration in Jakarta to protest non-Muslim governor, the 212 Mart, was also introduced as the Muslim-branded retail stores. 'Muslimpreneurs' in several big cities in Indonesia are interested to expand the Islamic retail business to the national level.

\subsection{Current retail practice in Malaysia}

The growth of international hypermarket retailers in the Malaysian market is rising. In Malaysia, retail industry is characterized by intensifying competition from both domestic and foreign companies. As of 2017, Tesco ranked first within hypermarkets, ahead of local and international players such as Cold Storage, Mydin Mohamed Holdings, AEON, Econsave and Jaya Grocer. The company's leading position 
can be attributed to the dominance of its hypermarket brands, Tesco and Tesco Extra (Euromonitor International, 2018). Other than large retail formats, such as hypermarkets, supermarkets, and lifestyle department stores, Malaysia also has traditional retail shops, such as convenience stores, provision stores, and specialty shops. These kinds of stores are still mushrooming due to increasing demand from the customers (Amine \& Lazzaoui, 2011).

To attract more customers and subsequently gain market share, retailers have been using various retail mixes, including pricing (Nagle \& Müller, 2017; Olbrich et al., 2017), and branding (Das, 2014). However, it is widely known that retailers adopted various strategies and becoming more innovative in acquiring market share. Among a new strategy is the incorporation of the Islamic concept in their store attributes (Abu Bakar \& Hussin, 2013).

\subsection{Retail Patronage and Customer Loyalty}

In marketing literature, several constructs and variables convey the same meaning. So does between patronage and loyalty. The similarity is both of them means 'repeat purchase.' However, these two constructs are different conceptually and theoretically.

In general, patronage can be defined as 'the support, especially financial, that is given to a person or an organization by a patron.' (Oxford English Dictionary). In the retail context, patronage is the reciprocity between a customer and the retail store (Blut et al., 2018). One research stream correlates retail patronage with the store, frequency of visit, and store choice ( $P a n \&$ Zinkhan, 2006). It is a multidimensional construct consisting of product-relevant (price, quality and product selection), marketrelevant (facilities, location, services, etc.) and personal-relevant factors (age, gender, income) (Pan and Zinkhan, 2006). Other studies included customer satisfaction (Ngo \& Pavelková, 2017; Babin, Darden, \& Griffin 1994), loyalty (Suebsaiaun \& Pimolsathean, 2018; Ngo \& Pavelková, 2017), food prices (Morkūnas et al, 2019), and WOM (Lacey, Suh \& Morgan, 2007) as well.

Consumer loyalty is another thing. In literature, there is still a problem in defining loyalty, whether it is based on the attitude or behavior only, or combination between attitude and behavior (Akun, 2012). The classical definition tends to use an only behavioral approach to measure loyalty. According to Dick and Basu (1994), measuring loyalty only based on the behavioral aspect is insufficient.

Therefore, Dick and Basu (1994) defined customer loyalty as "the strength of the relationship between an individual's relative attitude and repeat patronage." They separate loyalty into four types: loyalty, latent loyalty, spurious loyalty, and no loyalty. Loyalty occurs when a customer's relative attitude and repeat patronage is high. When a customer's relative attitude is high, but his/her repeat patronage is low; it is categorized as latent loyalty. Spurious loyalty occurs when a customer's relative attitude is low, but his/her repeat patronage is high. Finally, customers are no loyal if they have a low relative attitude and repeat patronage. In their framework, customer loyalty is formed by cognitive, affective, and conative antecedents moderated by situational influence and social norms.

The loyalty formation, including cognitive, affective, and conative, was also mentioned in Oliver (1999). He described loyalty as "a deeply held commitment to rebuy or re-patronize a preferred product/service consistently in the future, thereby causing repetitive same-brand or same-brand set purchasing, despite situational influences and marketing efforts having the potential to cause switching behavior."

From the above definition of loyalty, two things may distinguish it from retail patronage. First, theoretically, customer loyalty is influenced by cognitive, affective, and conative antecedents as described by Dick and Basu (1994) and Oliver (1999). Retail patronage model is unlike loyalty. It is influenced by product-relevant, market-relevant, and personal-relevant factors, as explained by Pan and Zinkhan (2006). 
Second, from Oliver (1999) definition, the object of loyalty is consumer product or service, however, in retail patronage, the object of re-patronize is not the consumer product or service but the store as mentioned by Pan and Zinkhan (2006) above. Repatronizing a retail store does not mean a customer is loyal to a product or service. They can be loyal to a store due to the combination of a store's product quality, facilities, services, or attachment. In the same way, a customer that is loyal to a product does not mean s/he is loyal to the store. A loyal customer will repurchase the specific product available at any retail store. Thus, customer loyalty is different from retail patronage.

\subsection{Self-Concept and self-congruity theory}

Rosenberg (1979) defined self-concept as 'the totality of an individual's thoughts and feelings having reference to himself as an object'. As this construct evolved, it's terminology triggered some discussions in psychology literature. The self-concept has two meanings which are self-esteem and self-consistency (Epstein, 1980). Self-concept is divided into actual and ideal self-concept or mostly termed as actual-self and ideal-self. Actual self refers to how a person perceives him or herself whereas the ideal self is the image of oneself as one would like to be.

In consumer behavior literature, Sirgy (1982) employed two constructs related to self-concept namely, self-image belief and self-image value. Self-image belief refers to the degree of belief associated with self-image. This definition is similar to actual self-concept. Therefore, the term self-image is similar to actual self-concept. Self-image value is defined as the degree of value attached to a specific actual selfconcept. On the other hand, it is equivalent to the ideal self-concept. In some papers, the term selfconcept is often termed as self-image. Sirgy (1982) for example, preferred to write the term as 'self-image' instead of 'self-concept'. Consequently, actual self-concept and ideal self-concept can also be found termed as actual self-image and ideal-self image. As the construct evolved, self-image has the other two dimensions namely, social self-image and ideal social self-image. Social self-image is the image that one believes others hold, whereas ideal social self-image is the image that one would like others to hold.

The discussion about self-image can lead to self-congruity in brand literature. Sirgy (1982) defined self-congruity as the condition where one's self-image is congruent with the typical brand-user image. It is applied in research evaluating brands. More specifically, Kim (2015) mentioned some topics, such as tourism, retailing, advertising and consumer psychology.

Self-congruity might affect purchase motivation in four different conditions. The first is positive selfcongruity, it happens when the positive perception toward a typical brand-user image meets the positive self-image belief. It is the strongest condition of self-congruity in affecting purchase motivation. The second is positive self-incongruity, the condition where there is a match between positive typical branduser image perception and negative self-image belief. The third is the negative self-congruity. This happens when the negative perception toward a typical brand-user image meets the negative self-image belief. On the other hand, when negative self-congruity happens, there will be no purchase motivation at all. The last is negative self-incongruity, which refers to a condition where a negative typical brand-user image perception matches positive self-image belief.

Most people often misunderstood between self-congruity and brand personality. Some tend to use both terms interchangeably (Helgeson \& Supphellen, 2004). Both are two distinct constructs with a discriminant effect in evaluating the decision to choose the brand (Parker, 2009). Brand personality is defined as 'a set of human characteristics associated with a brand' (Aaker, 1997), whereas as mentioned before, self-congruity is the fit between one's self-image and typical brand-user image. The concept might applied in an innovative products (Dabija, Al Pop, \& Săniuță, 2017), place brand (Hereźniak, Florek, \& 
Augustyn, 2018), nostalgic brands (Grebosz-Krawczyk, 2019), and employer brand (Urbancová \& Hudáková, 2017).

\section{HYPOTHESES DEVELOPMENT}

\subsection{Halal Product Quality(HPQ) and Retail Store Patronage Behavior (RPB)}

The product can be the source of competitive advantage (Zain \& Saidu, 2016) depending on the quality it has and the value it offers. Product quality is defined as a 'consumer's judgment regarding a product's overall excellence or superiority' (Zeithaml, 1988). Bergman and Klefsjo (1994) defined a qualified product as the product with the ability to satisfy the expected customer's needs.

Unlike the other, Muslim customers carefully choose to consume the products that are halal guaranteed. Muslim customers will be evaluating the components, production process and delivery of the products (Kockturk, 2002). In this case, it clear that a halal product is not determined by the ingredient alone, the supply-chain process must also be accounted for.

According to Hashim et al. (2014), Muslim customers are highly confident to purchase in a retail store that offers halal labeled products. A similar attitude also found by Fauzi et al (2016) that if the retail store is believed to serve the true halal, then the Muslim customers are willing to patronize the store. Therefore, the authors formulate that retail patronage behavior is determined by the halal product quality perceived by the customers.

H1: Halal product quality affects customer retail patronage behavior

\subsection{Halal Pricing (HP) and Retail Store Patronage Behavior (RPB)}

Price also an important part of the marketing mix. Quality product alone without reasonable and trusted price cannot create a purchase. Price and special promotions have been used to attract consumers to a retail store and generate an increased level of store traffic (Grewal et al., 1998). To explain the connection between price and retail patronage, the psychological concept appears to be helpful.

An adaption-level theory from the psychological field stated that one's basis of judgment is evaluated based on previous experience. It is also based on an individual's recollections of how he or she perceived similar stimuli in the past. The adaptation-level for judging the price of an item is called the internal reference price. The internal reference price also called the average market price, expected price or fair price(Grewal et al., 1998). Consequently, if the price of a product in a retail store is close to customers' internal reference price range, the customers' willingness to pay for the product is high.

Following the above arguments, perceived halal pricing in this research is conceptually defined as the customers' overall evaluations of the fairness of the product's price following the teaching in the Quran and Hadith. Based on Islamic teaching, the price charged on a product must be truthful. High price for low quality of the product is considered as untruthful or unfair. Additional price for the upgraded quality of the product needs to be clarified (Abdul Rahim \& Siti Rahayu, 2013). The purpose is to avoid unfair pricing perception. Therefore, the pricing that follows Islamic principle is more likely perceived as fair, and in the end, perceived halal pricing affects customers' decision to patronize a retail store.

H2: Halal pricing affects customer retail patronage behavior 


\subsection{Self-Congruity (RC) and Retail Store Patronage Behavior (RPB)}

Tsai (2001) defined retail re-patronage behavior as the likelihood that the consumer willing to revisit the store in the future. Retail patronage behavior is then can be defined as the likelihood that customers want to visit and shop at the store several times. From the self-congruity theory discussed earlier, it is known that purchase motivation occurs when a positive self-congruity meets a positive brand image. It can also be inferred that customers will not decide to patronize retail store only based on the good image the brand has or the brand-user image has. There must be a matching process between user-brand image and self-image. According to Sirgy, Grewal, and Mangleburg (2000), the likelihood of the shopper to patronize retail store is higher when there is a greater match between store patron image and consumer self-concept. The matching process should not leave self-consistency, self-esteem, social-consistency, and social approval motives (Kim, 2015). From this argument, the authors hypothesize that retail patronage behavior is also determined by the self-congruity.

\section{H3: Self-congruity affects customer retail patronage behavior}

\subsection{Self-Congruity (SC) and Halal Product Quality (HPQ)}

The product is said to be halal when it meets certain requirements. As Kocturk (2002) mentioned, besides the quality ingredients, halal products must also consider the production and delivery process. The retail store must sell only product that is halal-guaranteed, or certified by the special body in charge with this. However, recent findings by Aji (2017) indicated that some customers hold a skeptical attitude toward the halal certification process. This condition will later impact on the decision to visit and purchase to a retail store. In this context, when positive self-congruity occurs, -the shopper believes that the product sold in a retail store is halal, and s/he also perceives that people who bought the product due to the halal conformity-, the product will have higher perceived halal quality. In short, the authors formulate that self-congruity affects the perception toward halal product quality.

H4: Self-congruity affects halal product quality perception

\subsection{Self-Congruity (SC) and Halal Pricing (HP)}

Following Islamic law, the price charged to customers must be fair and free from deception as well as riba (Hashim et al, 2014). Higher prices for quality upgrades must also be clarified (Abdul Rahim and Siti Rahayu, 2013). As for the perceived halal product quality, perceived halal perception is determined by selfcongruity which is the match between individual self-belief and typical brand-user image. The shopper is possible to willing to pay for the price as if the price is judged to be fair and believe that the other will perceive so. Chung (2017) in the context of clothing evaluation shown how self-image congruence affects clothing preference and payment intention. Women respondents in Chung's (2017) study intended to pay the price as if they prefer the cloth, and clothing preference determined by self-image congruity. In this paper, the authors then hypothesize that shoppers will perceive the positive halal pricing in a retail store if there is a positive self-image congruence, which is the match between shopper's belief of the halal pricing and the image of other shoppers willing to pay for the price.

H5: Self-congruity affects halal pricing perception 


\subsection{Self Congruity (SC) and Islamic Store Image (ISI)}

Islamic store image (ISI) is conceptually defined as the shoppers' perception of the overall Islamic image of a retail store based on three image dimensions mentioned by Semeijn (2004)namely, layout, merchandise and service quality. Self congruity in this paper comprising four dimensions, such as actual self-congruity, ideal self-congruity, social self-congruity, and ideal social self-congruity. Beside self-motive, social-consistency and social motives are highly potential to influence perception (Kim, 2015). Socialconsistency refers to the tendency to maintain a self-image held by significant others (Sirgy et al, 2000).

In a mall setting, El-Hedhli and Kamel (2017) found that customers make inferences about the stereotypic image of the typical mall shopper based on their perceptions (self-image belief). Customer, according to Louis and Lombart (2011), prefers the store which is appropriate with his image. Therefore, following the self-congruity theory, the purchase motive is higher when there is a positive match between self-image and brand-user image. Shoppers will associate the positive Islamic image of a retail store as long as there is a positive self-congruity. This leads the authors to formulate that Islamic store image (ISI) is affected by self congruity.

H6: Self-congruity affects Islamic store image

\subsection{Self-Congruity (SC) and Islamic Store Atmosphere (ISA)}

The match between shopper's self-image and user image might result in either negative or positive perceptions about the product, price, store image, and atmosphere. This to supports that self-congruity as the personal factor is the most important variable in the Islamic retail patronage model. That notion is empirically supported by Kim and Park (2016). They showed that sophistication as the congruity factors between store image and consumer self-image affected the perceived store atmosphere. The authors, therefore, argue that self-congruity influences the perception about Islamic image of a store.

H7: Self-congruity affects the perceived Islamic store atmosphere

\subsection{Islamic Store Atmosphere(ISA) and Retail Store Patronage Behavior (RPB)}

A pleasant atmosphere in a retail store is desired by customers. Store atmosphere might affects the success of a retail outlet (Hussain \& Ali, 2015). The atmosphere can be a stimulus that leads to some cognitive effects within the individual which, in turn, leads to some behavioral responses (Turley \& Milliman, 2000). Leischnig, Schwertfeger, and Geigenmüller (2011) shown that unique shopping experience might impact on customer attitude and satisfaction towards a retail brand.

According to Turley and Miliman (2000), there are five atmospheric stimulates namely: exterior (ex: storefront, building architecture), general interior (ex: sounds, temperature, cleanliness), store layout (ex: product grouping, traffic flow), interior display(product display, signs), and human(ex: crowding, employee uniform). Islamic retail atmosphere here defined as the atmospheres, including five atmospheric stimuli mentioned by Turley and Miliman (2000), that adopt Islamic cultures, traditions or values. The examples for the Islamic atmospheres such as the cleanliness of the store (Hashim, Hussin \& Zainal, 2014), the use of Islamic-based music or back sound, and the Quran recitation (general exterior), sales personnel with modest outfits (human), Islamic decorations (exterior) and so forth.

Hashim et al. (2014) found that Muslim customers perceived retail stores that have a comfortable and clean atmosphere as Islamic. In another study, it was found that a positive store environment, such as an attractive layout, effective display, pleasant scent, and music, may influence customers to lengthen their 
stay at a store and revisit a store (Baker et al., 2002). Therefore, it can be synthesized that Muslim customers are willing to patronize a retail store with Islamic atmosphere. The authors hypothesize that:

H8: Islamic store atmosphere affects customer retail patronage behavior

\subsection{Islamic Store Atmosphere (ISA) and Islamic Store Image (ISI)}

Retail stores will develop targeting strategies to position the positive image on shoppers eyes. Giant hypermart in Indonesia and Malaysia targeted middle-low customers. The question is, how, therefore, the customers catch the targeting strategies developed by the retail stores to build a certain image? They will use certain cues from the retail environments to form the impression of the store (Sirgy, Grewal \& Mangleburg, 2000). It was supported by empirical findings, for instance, Schlosser (1998) found that store atmosphere affects merchandise quality inferences, which in turn affecting store image. Chang and Luan (2010) demonstrated that the store atmosphere became the most important factor influencing store image. Thus, in this research, Islamic store image can be perceived by the shoppers if all the atmospheric cues within the retail stores show Islamic nuance.

H9: Islamic store atmosphere affects Islamic store image

\subsection{Islamic Store Image(ISI) and Retail Store Patronage Behavior (RPB)}

Store image can be defined firstly by Martineau (1958) as the consumer's perception either by functional qualities or by an aura of the psychological attribute. It is also defined as the complex of a consumer's perceptions of a store on different (salient) attributes (Seock, 2009). The store image reflects store identity (Demirgüneş, 2014). Earlier research has shown that the retail stores have two main facets, core and peripheral. The core facets of the retail stores are price and merchandise, whereas the peripheral facets are policy and service (Jacoby, 1986; Mark, 1976). Store image has nine dimensions as first conceptualized by Lindquist (1974), namely merchandise, service, clientele, physical facilities, convenience, promotion, store ambiance, institutional factors, and post-transaction satisfaction. All nine together must be achieved to get a positive store image, since it is the sum of attributes or as the overall perception that consumers have about the store (Ngobo \& Jean, 2012).

It was proven by prior studies that purchase intention is affected by the store image (Chen, Tsing, and Tsou, 2009, Grewal et al, 1998). The relationship might occur because the shoppers associate the store image by certain cues, such as merchandise, service quality and store layout (Smeijn et al., 2004). In the literature, it is termed as the cue utilization theory (Diallo, 2012). In this research, customer's motive to patronize an Islamic retail store is coming from the Islamic image derived from the cues utilized. This leads the authors to hypothesize that Islamic store image affects retail patronage behavior.

H10: Islamic store image affects customer retail patronage behavior

\section{METHODOLOGY}

\subsection{Sampling}

A purposive sampling technique was used for this paper. To ensure patronize behavior, respondents were selected among retail customers in Indonesia and Malaysia who have visited the Islamic retail stores more than 3 times in a week. There is a filter question such as, "during a week, bow many times bave you visited 
this store?'. Consequently, respondents who visited the Islamic retail stores less than 3 times a week are eliminated from the analysis.

In SEM, there is still no consensus on how many is the appropriate sample size for SEM. Hoyle and Kenny (1999, p. 391) said that even if the sample size is small, the SEM Models could be meaningfully tested. According to Anderson and Gerbing (1988), normally, a minimum sample size for SEM ranging from 100-150. If there is no missing data and the data is normally distributed, $\mathrm{N}=150$ can be considered reasonable for conducting CFA (Wang \& Wang, 2012; Muthen \& Muthen, 2002). Nunally (1967) provided the most widely accepted rule of thumb for adequate sample size determination, which is 10 cases per indicator. Roscoe (1975) also gave his criteria for minimum and maximum sample size. 5 cases per indicator are considered as a minimum, while 10 cases per indicator are the maximum

In this paper, there is a total of 610 samples from both Indonesia and Malaysia. From Indonesia, there are 302 samples and 308 samples from Malaysia. There are 37 total questions or indicators asked.

Following Anderson and Gerbing (1988), Wang and Wang (2012), and Muthen and Muthen (2002)'s criteria, sample size determination in this paper is still acceptable statistically. Furthermore, following Nunally's (1967) and Roscoe's (1975) criteria, the minimum sample size is $37 x 5=185$ and the maximum is $37 \times 10=370$. Therefore, 185-370 samples become an acceptable range of sample sizes. Thus, the sample size in this paper for Indonesia (302) and Malaysia (308) is also acceptable statistically.

\subsection{Measure and questionnaire development}

Data for this paper are gathered by the primary data collection method through online questionnaires. The questionnaire contains two sections. In the first section, some demographic questions were gathered. In the next section, respondents were requested to answer questions relating to the patronage behavior, on a five-point Likert scale, ranging from "strongly agree" to "strongly disagree".

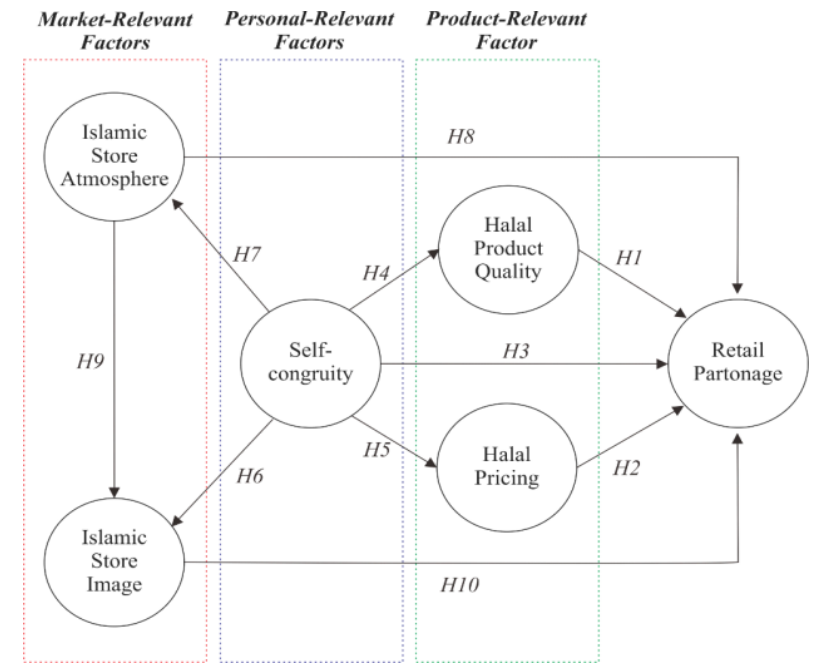

Figure 1. Research model

All items intended to measure the variables in this paper are taken from previously validated instruments and modified so that the focus is on patronage behavior. The construct of retail patronage behavior is measured by scales from Osman (1993). The construct of self-congruity is measured by scales from Sirgy and Su (2000) and Brannen and Frisby (2017), while halal pricing is measured by scales from Hashim et al (2014). On the other hand, halal product quality and Islamic store atmosphere are assessed by measurements reported by Hashim et al. (2014) and Fauzi et al. (2016), while Islamic store image is measured with scales from Semeijnet al. (2004). The research hypothetical model is shown in Figure 1. 


\subsection{Data analysis}

To test the hypothesized model, AMOS-Structural Equation Modeling (SEM) was implemented. In SEM, there are two tests that need to be conducted which are measurement and structural model tests. The measurement model test is conducted to test all items' validity. The technique used in this test is Confirmatory Factor Analysis (CFA). The hypotheses are examined in the structural model test if all items used passed the CFA. In SEM, hypotheses are supported if the p-value for each estimate or beta score is less than 0.05. The multi-group analysis is used to compare the patronage behavior between both countries. The participants for this paper comprised 302 retail customers in Indonesia and 308 retail customers in Malaysia.

\section{RESULTS}

\subsection{Measure and questionnaire development}

Factor analysis using principal component analysis is conducted to test the construct validity and internal consistency. As a rule of thumb, loadings lower than 0.50 should pose a problem (Hair et al., 2006). Based on the analysis eight items (HPQ1, ISI1, ISI2, ISI7, ISI 8, ISI9, ISI10, and ISI11) had loading below the recommended value of 0.50 . Those items are removed from the model. Factor loading values are obtained using Varimax rotation. Table 2 shows the results of the factor analysis.

\subsection{Structural model results}

The research model presented is tested with AMOS 21.0 software. The model fit is assessed using two fitness categories which are absolute fit indices and incremental fit indices. The model fit is assessed by the chi-square/degrees of freedom (CMIN/DF), goodness-of-fit index (GFI), adjusted goodness of fit index (AGFI), root mean square error of approximation (RMSEA), normed fit index (NFI) and comparative fit index (CFI). Not all goodness-of-fit indicators in this paper met the threshold standards, such as GFI (0.866 - nearly good), AGFI (0.836 - nearly good), and NFI (0.887 - nearly good). However, those results do not mean that the structural model is not good at all. Other criteria may provide support for the model fit. CMIN/DF, RMSEA, and CFI score are 3.600 (acceptable), 0.006 (good) and 0.915 respectively (good). Therefore, it can be concluded that the goodness-of-fit criteria for the model are met and thus can be brought into further analysis.

Table 1

Hypothesis testing result

\begin{tabular}{|c|c|c|c|}
\hline Hypothesis & Causal path & Path & Result \\
\hline H1 & Retail patronage Halal product quality & 0.07 & Unsupported \\
\hline H2 & Retail patronage Halal pricing & $0.65^{* *}$ & Supported \\
\hline H3 & Retail patronage Self-congruity & $0.20^{* *}$ & Supported \\
\hline H4 & Halal product quality Self-congruity & $0.46^{* *}$ & Supported \\
\hline H5 & Halal pricing Self-congruity & $0.49^{* *}$ & Supported \\
\hline H6 & Islamic store image Self-congruity & $0.20^{* *}$ & Supported \\
\hline H7 & Islamic store atmosphere Self-congruity & $0.66^{* *}$ & Supported \\
\hline H8 & Retail patronage Islamic store atmosphere & -0.06 & Unsupported \\
\hline H9 & Islamic store image Islamic store atmosphere & $0.32^{* *}$ & Supported \\
\hline H10 & Retail patronage Islamic store image & $0.17^{* *}$ & Supported \\
\hline
\end{tabular}

Note: ** p-value $<0.01$ 
Table 2

Factor analysis

\begin{tabular}{|c|c|c|c|c|c|c|c|c|}
\hline \multirow[b]{2}{*}{ Code } & \multirow[b]{2}{*}{ Statement } & \multicolumn{6}{|c|}{ Factors } & \multirow[b]{2}{*}{ Reliability } \\
\hline & & $\begin{array}{c}\text { Self- } \\
\text { Congruity }\end{array}$ & $\begin{array}{c}\text { Halal } \\
\text { Pricing }\end{array}$ & \begin{tabular}{|c} 
Islamic \\
Store \\
Atmospher \\
$\mathrm{e}$
\end{tabular} & $\begin{array}{l}\text { Halal } \\
\text { Product } \\
\text { Quality }\end{array}$ & $\begin{array}{c}\text { Retail } \\
\text { Patronage } \\
\text { Behavior }\end{array}$ & $\begin{array}{l}\text { Islamic } \\
\text { Store } \\
\text { Image }\end{array}$ & \\
\hline SC2 & $\begin{array}{l}\text { This user of this Islamic retail } \\
\text { store is a mirror image of me }\end{array}$ & 0.821 & & & & & & \\
\hline SC4 & $\begin{array}{l}\text { This user of this Islamic retail } \\
\text { store is a mirror image of the } \\
\text { person I would like to be }\end{array}$ & 0.786 & & & & & & \\
\hline SC3 & $\begin{array}{l}\text { This personality of the user of } \\
\text { this Islamic retail store is } \\
\text { consistent with how I would like } \\
\text { to be }\end{array}$ & 0.765 & & & & & & \\
\hline SC5 & $\begin{array}{l}\text { The image of the typical customer } \\
\text { of this Islamic retail store is } \\
\text { similar to how others believe that } \\
\text { I am }\end{array}$ & 0.749 & & & & & & 0.868 \\
\hline SC1 & $\begin{array}{l}\text { The personality of the shopper of } \\
\text { this Islamic retail store is } \\
\text { consistent with how I see myself }\end{array}$ & 0.717 & & & & & & \\
\hline SC6 & $\begin{array}{l}\text { This Islamic retail store is } \\
\text { consistent with how I would like } \\
\text { others to see me }\end{array}$ & 0.711 & & & & & & \\
\hline PRC7 & Price is reasonable & & 0.705 & & & & & \\
\hline PRC5 & Price is not a burden & & 0.690 & & & & & \\
\hline PRC1 & The price is not a fraud & & 0.668 & & & & & \\
\hline PRC6 & $\begin{array}{l}\text { Original and additional price are } \\
\text { disclosed }\end{array}$ & & 0.606 & & & & & 0890 \\
\hline PRC4 & Higher price, higher quality & & 0.586 & & & & & 0.890 \\
\hline PRC2 & The price is free from riba (usury) & & 0.569 & & & & & \\
\hline PRC3 & $\begin{array}{l}\text { The price charged is based on the } \\
\text { guidelines from the Qur'an and } \\
\text { Sunnah }\end{array}$ & & 0.564 & & & & & \\
\hline ISA3 & $\begin{array}{l}\text { The background (music or } \\
\text { instrumental) played is Islamic }\end{array}$ & & & 0.835 & & & & \\
\hline ISA5 & \begin{tabular}{|l} 
The store uses \\
architecture or design
\end{tabular} & & & 0.826 & & & & \\
\hline ISA1 & \begin{tabular}{|l}
$\begin{array}{l}\text { The store is clean and } \\
\text { comfortable }\end{array}$ \\
\end{tabular} & & & 0.672 & & & & 0.852 \\
\hline ISA4 & \begin{tabular}{|l} 
The employees dressed using \\
Islamic dresses (ex: women \\
wearing hijab)
\end{tabular} & & & 0.610 & & & & \\
\hline ISA2 & $\begin{array}{l}\text { There are halal signs for every } \\
\text { product }\end{array}$ & & & 0.590 & & & & \\
\hline HPQ2 & $\begin{array}{l}\text { The products offered by Islamic } \\
\text { retail store are varied }\end{array}$ & & & & 0.788 & & & \\
\hline HPQ4 & $\begin{array}{l}\text { Islamic retail store sells many } \\
\text { halal products from a variation of } \\
\text { brands }\end{array}$ & & & & 0.775 & & & 0803 \\
\hline HPQ3 & $\begin{array}{l}\text { The source of product halalness is } \\
\text { clear or unambiguous }\end{array}$ & & & & 0.754 & & & 0.893 \\
\hline HPQ5 & $\begin{array}{l}\text { The products offered by Islamic } \\
\text { retail store have halal logo } \\
\text { attached on the packaging. }\end{array}$ & & & & 0.749 & & & \\
\hline RPB2 & $\begin{array}{l}\text { The propensity to shop at the } \\
\text { store in the future }\end{array}$ & & & & & 0.809 & & \\
\hline RPB3 & $\begin{array}{l}\text { The tendency to shop at a } \\
\text { particular store in compare with } \\
\text { other available stores }\end{array}$ & & & & & 0.795 & & 0.865 \\
\hline
\end{tabular}




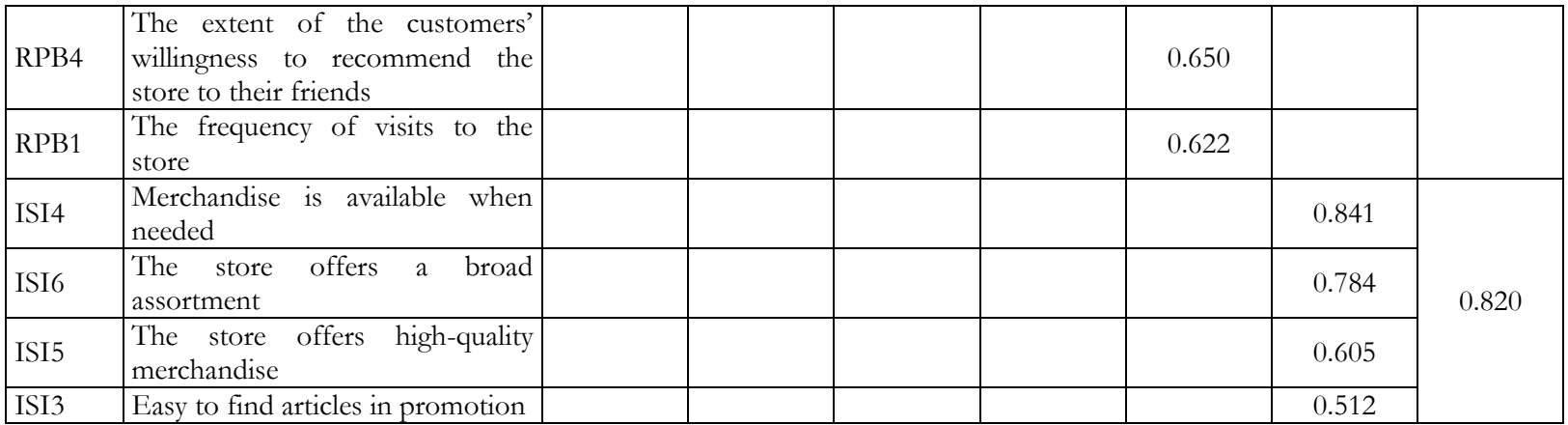

The results of testing the structural model are presented in Table 1. All hypothesized paths were statistically significant, except for $\mathrm{H} 1(\beta=0.07$, $\mathrm{p}$-value $>0.05)$ and $\mathrm{H} 8(\beta=-0.06$, $\mathrm{p}$-value $>0.05)$. The $\beta$ or estimate score for $\mathrm{H} 2, \mathrm{H} 3, \mathrm{H} 4, \mathrm{H} 5, \mathrm{H} 6, \mathrm{H} 7, \mathrm{H} 9$ and $\mathrm{H} 10$ are $0.65,0.20,0.46,0.49,0.20,0.66,0.32$, and 0.17 respectively, significant at p-value $<0.01$. Therefore, for $\mathrm{H} 2, \mathrm{H} 3, \mathrm{H} 4, \mathrm{H} 5, \mathrm{H} 6, \mathrm{H} 7, \mathrm{H} 9$ and $\mathrm{H} 10$ are supported. Since H1 and H8 are not statistically significant, therefore both hypotheses are not supported.

Table 3

Results of Multigroup Analyses

\begin{tabular}{|l|c|}
\hline \multicolumn{1}{|c|}{ Causal path } & Diff \\
\hline Retail patronage Halal product quality & 0.809 \\
\hline Retail patronage Halal pricing & 0.191 \\
\hline Retail patronage Self-congruity & 0.995 \\
\hline Halal product quality Self-congruity & 0.003 \\
\hline Halal pricing Self-congruity & 0.192 \\
\hline Islamic store image Self-congruity & 0.863 \\
\hline Islamic store atmosphere Self-congruity & 0.717 \\
\hline Retail patronage Islamic store atmosphere & 0.383 \\
\hline Islamic store image Islamic store atmosphere & 0.997 \\
\hline Retail patronage Islamic store image & 0.362 \\
\hline
\end{tabular}

The multi-group analysis was also conducted to compare and test the significant difference between the Islamic retail patronage behavior among customers between Indonesia and Malaysia. The overall results revealed that there is no significant difference in the Islamic retail patronage behavior between Indonesia and Malaysia consumers, except for self-congruity and halal product quality relationships. On that relationship, p-value difference is lesser than 0.01, which means Indonesia and Malaysia consumers differ in their self-congruity and halal product quality perception. This multi-group analysis result suggesting that the measurement model may be robust across cultures and that the factor loading pattern and factor loadings appeared to be equivalent across the cultures examined. The results of the multi-group analyses are shown in Table 3.

\section{DISCUSSION AND CONCLUSION}

The purpose of this paper is twofold; to test and validate the Islamic retail patronage behavior framework and to compare the Islamic retail patronage among customers between Indonesia and Malaysia. The overall findings of this paper confirmed the association among halal pricing and retail patronage (H2), self-congruity and retail patronage (H3), self-congruity and halal product quality (H4), self-congruity and halal pricing (H5), self-congruity and Islamic store image (H6), self-congruity and 
Islamic store atmosphere (H7), Islamic store atmosphere and Islamic store image (H9) and also Islamic store image and retail patronage (H10). Based on the findings, all the hypotheses were supported except for $\mathrm{H} 1$ (halal product quality and retail patronage) and H8 (Islamic store atmosphere and retail patronage).

The unsupported finding of hypothesis 1 did not give support to Hashim et al (2014) and Fauzi et al (2016) who stated that Muslim customers will be confident to patronize retail stores serving true halal products. It can be implied from this finding that halal product quality alone is not enough without incorporating another quality. In hypotheses 2 of this research is found that pricing becomes a significant predictor of retail patronage. These two findings might be correlated. halal product quality is important to ensure retail store patronize only if the price itself is also 'halal'. This argument suggests future research to conduct the indirect effect of halal product quality on retail store patronage.

Islamic store atmosphere is also found insignificantly affecting retail store patronage. It is mentioned before that according to Hashim et al. (2014), Muslim customers perceived cleanliness and a comfortable atmosphere as Islamic, which is positive. A positive atmosphere affects retail outlet success (Hussain and Ali, 2015). It is also supported by Baker's et al (2002) statement who found that a positive store environment will lead to store visits and revisit. From hypothesis 2 testing finding, it can be implied that positive Islamic atmosphere is not the main predictor of retail store patronage. There is a possibility for indirect effect of Islamic atmosphere on retail patronage through Islamic retail store image. That argument is based on the H9 and H10 supported findings. Therefore, it can be the agenda for future research to analyze the role of Islamic store image in mediating Islamic store atmosphere and retail patronage.

This paper also compares and tests the significant difference between Islamic retail patronage behavior among customers in Indonesia and Malaysia. The results revealed that there is no significant difference in the Islamic retail patronage behavior among Indonesia and Malaysia consumers, suggesting that the measurement model may be robust across cultures and that the factor loading pattern and factor loadings appeared to be equivalent across the cultures examined.

As a whole, retailers should take into consideration all the important variables of halal pricing, selfcongruity, and Islamic store image in their conduct of business as the results have indicated that all the dimensions are positively related to retail patronage, except for Halal product quality and Islamic store atmosphere which was not found to have any relation with retail patronage.

Although the results revealed that customers nowadays generally do not expect stores to have Islamic atmosphere and comparable product quality, this does not mean the retailer should turn a blind eye to this aspect. Having these two elements around will enforce the customer's overall patronage behavior towards the stores. Nonetheless, retailers should pay closer attention to the three of the most important factors, self-congruity, pricing, and Islamic store image. Self-congruity in this paper context is special since it becomes the main determinant of halal pricing and Islamic store image perception.

\section{LIMITATION AND FUTURE RESEARCH}

This paper has several limitations. First, it focuses only on Islamic retail patronage behavior in Indonesia and Malaysia; the results, therefore, cannot be generalized to other patronage behavior in another country. Thus, there is a need to commence further studies in other settings. Second, this paper only considered five variables which influence the patronage behavior, and the factors selected may not cover all the factors that could influence Islamic retail patronage behavior. Hence, further research could take into account other factors that may also influence consumers' patronage behavior. 


\section{REFERENCES}

Aaker, J. L. (1997). Dimensions of brand personality. Journal of Marketing Research, 34, 347-356.

Abu Bakar, A.R., \& Hussin, S.R. (2013). What constitutes an Islamic retailer? Islamic store attributes from the perspectives of Islamic marketing principles. International Journal of Sales, Retailing and Marketing, 2(1), 74-84.

Aji, H.M. (2019). Halal tourism is not Islamic tourism, retrieved May 24, 2020 from https://www.thejakartapost.com/academia/2019/07/05/halal-tourism-is-not-islamic-tourism.html

Aji, H. (2017). Examining the moderating role of high-versus-low scepticism toward Halal labels: findings from Indonesia. International Journal of Islamic Marketing and Branding, 2(4), 278-303.

Akun, E. (2012). Literature Review and Discussion on Customer Loyalty and Consciousness. European Journal of Economics, Finance and Administrative Sciences, 51, 158-173

Al-hyari, K., Alnsour, M., \& Al-weshah, G. (2012). Religious beliefs and consumer behaviour: from loyalty to boycotts. Journal of Islamic Marketing, 3(2), 155-174.

Amine, A., \& Lazzaoui, N. (2011). Shoppers reaction to modern food retailing systems in an emerging country: The case of Morroco. International Journal of Retail and Distribution Management, 39(8), 562-581.

Anderson, J.C., \& Gerbing, D.W. (1988). Structural equation modeling in practice: A review and recommended two step approach. Psychological Bulletin, 103, 411-423

Babin, B.J., Darden, W.R.,\& Griffin, M. (1994). Work and/or Fun: Measuring Hedonic and Utilitarian Shopping Value.Journal of Consumer Research, 20(4), 644-56.

Baker, J., Parasuraman, A., \& Grewal, D. (2002). The Influence of Multiple Store Environment Cues on Perceived Merchandise Value and Patronage Intentions.Joumal of Marketing, 66 (2), 120-141.

Battour, M., \& Ismail, M.N. (2016). Halal tourism: Concepts, practises, challenges and future. Tourism Management Perspective, 19, 150-154

Bergman, B., \& Klefsjo, B. (1994). Statistics and TQM in industrial continuing education. International Journal of Continuing Engineering Education and Life-Long Learning, 4(1-2), 114-121.

Blut, M., Teller, C., \& Floh, A. (2018). Testing retail marketing-mix effects on patronage: a meta-analysis.Journal of Retailing, 94(2), 113-135

Brannen, J., \& Frisby, C. M. (2017). Self-Esteem's moderation of self-congruity effects on brand loyalty. Theoretical Economics Letters, 7(6), 1848-1864.

Chang, E-C., \& Luan, B. (2010). Chinese consumers' perception of hypermarket store image. Asia Pacific Journal of Marketing and Logistics, 22(4), 512-527

Chen, J,S., Tsing, R.K.H., \& Tsou, H.T. (2009). Multi-channel store image and the effects on purchase intention.The Service Industries Journal, 29(9), 1215-1230.

Chung, I.H. (2017). Effect of self-image congruence, clothing preference, and reference price on payment intention price.Journal of the Korea Society of Clotbing and Textiles, 40(1), 148-157

Dabija, D. C., Al Pop, N., \& Săniuță, A. (2017). Innovation in do-it-yourself retail: an empirical study on generation $\mathrm{X}$ among professional craftsmen and consumers. Economics \& Sociology, 10(2), 296.

Das, G. (2014). Impacts of retail brand personality and self-congruity on store loyalty: The moderating role of gender. Journal of Retailing and Consumer services. 21(2), 130-138.

Demirgüneş, B.K. (2016). The Antecedents of Store Image and Customer Satisfaction. International Journal of Research in Business and Social Science, 3(3), 48-62

Diallo, M. F. (2012). Effects of store image and store brand price-image on store brand purchase intention: Application to an emerging market. Journal of Retailing and Consumer Services, 19(3), 360-367.

Dick, A.S., \& Basu, K. (1994). Customer loyalty: toward an integrated conceptual framework. Journal of The Academy of Marketing Science, 22(2), 99-113

Douglass, S. L., \& Shaikh, M. A. (2004). Defining Islamic education: Differentiation and applications.Current Issues in Comparative Education, 7(1), 5-18

Epstein, S. (1980). The self-concept: a review and the proposal of an integrated theory of personality. In E. Staub (Ed.), Personality: Basic Issues and Current Research (pp. 82-132), Englewood Cliffs, NJ: Prentice-Hall

Euromonitor International. (2018). Country Report: Hypermarkets in Malaysia. 
Fauzi, W.I.M., Muhammad, N., Mokhtar, S.S.M., \& Yusoff, R.Z. (2016). What motivate Muslim consumer to patronage Islamic based-retail store? International Review of Management and Marketing, 6(7 Special Issue), 199203.

Grebosz-Krawczyk, M. (2019). Attitudes of young consumers towards international nostalgic brands-the comparative study. Economics \& Sociology, 12(3), 181-191.

Grewal, D., Krishnan, R., Baker, J., \& Borin, N. (1998). The effect of store name, brand name and price discounts on consumers' evaluations and purchase intentions. Journal of Retailing, 74(3), 331-352.

Hair, J., Black, W., Babin, B., Anderson, R., \& Tatham, R. (2006). Multivariate Data Analysis, 6th ed., Pearson Education, New York, NY.

Hashim, H., Hussin, S. R., \& Zainal, N. N. (2014). Exploring Islamic retailer store attributes from consumers perspectives: An empirical investigation. International Journal of Economics and Management, 8(Special issue), 117136.

Helgeson, J. G., \& Supphellen, M. (2004). A conceptual and measurement comparison of self- congruity and brand personality: The impact of socially desirable responding. International Journal of Market Research, 46, 205-233.

Hereźniak, M., Florek, M., \& Augustyn, A. (2018). On Measuring Place Brand Effectiveness-between Theoretical Developments and Empirical Findings. Economics \& Sociology, 11(2), 36-51.

Hoyle, R.H., \& Kenny, D.A. (1999). Sample size, reliability, and tests of statistical mediation, in Statistical Strategies for Small Sample Research (ed. R.H. Hoyle), Sage, Thousand Oaks, CA, pp. 195-222

Hussain, R., \& Ali, M. (2015). Effect of store atmosphere on consumer purchase intention. International Journal of Marketing Studies, 7(2), 35-43.

Kompas. (2016). Aprindo: Industri Ritel Tumbuh Sekitar 10 Persenpada 2016. Retrieved fromhttp://ekonomi.kompas.com/read/2016/12/28/172204826/aprindo.industri.ritel.tumbuh.sekitar.10.per sen.pada.2016

$\begin{array}{lllll}\text { Kontan. } & \text { (2017). } & \text { Aprindooptimisriteltumbuh } & 9 \% & \text { tahunini. }\end{array}$ fromhttp://industri.kontan.co.id/news/aprindo-optimis-ritel-tumbuh-9-tahun-ini

KEMENDAG (2017). Buka HBDI, Mendag: momentum sejajarkan merek lokaldengan merek internasional. siaran pers biro hubungan masyarakat. Retrieved November 24, 2017 fromwww.kemendag.go.id.

Kim, J.-H. (2015). Self-congruity effects: A critical review and an integrative model. Japanese Psychological Research, $57(4), 348-362$.

Kim, K.H., \& Park, M. (2016). The effect of the congruity between self-image and image of a multi-brand store on store attributes and consumer responses. Journal of the Korea Society of Clothing and Textiles, 40(1), 12-25

Knoferle, K. M., Spangenberg, E. R., \& Herrmann, A. (2012). It is all in the mix: The interactive effect of music tempo and mode on in-store sales. Marketing Letters, 23(1), 325-337.

Kocturk, T. (2002). Food rules in the Koran. Scandinavian Journal of Food \& Nutrition, 46(3), 137-139.

Lacey, R., Suh, J., \& Morgan, R.M. (2007). Differential effects of preferential treatment levels on relational outcomes. Journal of Service Research, 9(3), 241-56.

Leischnig, A., Schwertfeger, M., \& Geigenmüller, A. (2011). Shopping events, shopping enjoyment, and consumers' attitudes toward retail brands - An empirical examination. Journal of Retailing and Consumer Services, 18(3), 218223.

Lindquist, J.D. (1974). Meaning of image: a survey of empirical and hypothetical evidence. Journal of Retailing, 50(4), 29-38.

Louis, D., \& Lombart, C. (2011). Image and personality: Two complementary tools to position and differentiate retailers. International Management Review. 7(1), 66-73.

Martineau, P. (1958). The personality of the retail store. Harvard Business Review, 36 (January-February), 47-55.

Milliman, R. E. (1986). The influence of background music on the behavior of restaurant patrons. Journal of Consumer Research, 13(2), 286-289.

Mokhlis, S. (2009). Relevancy and measurement of religiosity in consumer behavior research. International Business Research, 2(3), 75-84.

Morkūnas, M., Volkov, A., \& Galnaityte, A. (2019). Government or invisible hand? Who is in charge of retail food prices? Evidence from the Baltics. Journal of International Studies, 12(3), 147-157. 
Muthen, L.K., \& Muthen, B. (2002) How to use a Monte Carlo study to decide on sample size and determine power. Structural Equation Modeling, 4, 599-620.

Nagle, T.T., \& Müller, G. (2017). The strategy and tactics of pricing: A guide to growing more profitably. Routledge.

Ngo, V. M., \& Pavelková, D. (2017). Moderating and mediating effects of switching costs on the relationship between service value, customer satisfaction and customer loyalty: investigation of retail banking in Vietnam. Journal of International Studies, 10(1), 9-33.

Ngobo, P. V., \&Jean, S. (2012). Does store image influence demand for organic store brands? Journal of Retailing and Consumer Services. 19(6), 621-628.

Nunnally, J.C. (1967) Psychometric Theory, McGraw-Hill, New York, NY.

Olbrich, R., Jansen, H. C., \& Hundt, M. (2017). Effects of pricing strategies and product quality on private label and national brand performance. Journal of Retailing and Consumer Services, 34, 294-301.

Oliver, R. L. (1999). Whence consumer loyalty? Journal of Marketing, 63(4), 33-44.

Osman, M.Z. (1993). A conceptual model of retail image influence on loyalty patronage behavior. International Review of Retail, Distribution and Consumer Research, 3(2), 133-148.

Pan, Y., \& Zinkhan, G. M. (2006). Determinants of retail patronage: A meta-analytical perspective. Journal of Retailing, $82(3), 229-243$.

Parker, B. T. (2009). A comparison of brand personality and brand user-imagery congruence. Journal of Consumer Marketing, 26, 175-184.

Pettijohn, L.S., Mellott, D. W., \& Pettijohn, C. E. (1992). The relationship between retailer image and brand image. Psychology and Marketing. 9(4), 311-328.

Roscoe, J.T. (1975), Fundamental Research Statistics for the Behavioural Sciences, 2nd edition. Holt Rinehart and Winston, New York, NY

Rosenberg, M. (1979). Conceiving the self. New York, NY: Basic Books.

Schlosser, A.E. (1998). Applying the functional theory of attitudes to understanding the influence of store atmosphere on store inferences. Journal of Consumer Psychology, 7(4), 345-369.

Seock, Y.K. (2009). Influence of retail store environmental cues on consumer patronage behavior across different retail store formats: An empirical analysis of US Hispanic consumers. Journal of Retailing and Consumer Services. 16(5), 329-339.

Sheau-Fan, Y., Sun-May, L., \&Yu-Ghee, W. (2012). Store brand proneness: Effects of perceived risks, quality and familiarity. Australasian Marketing Journal (AMJ), 20(1), 48-58.

Sirgy, M.J. (1982). Self-Concept in Consumer Behavior: A Critical Review. Journal of Consumer Research,9(3), 287-300.

Sirgy, M.J., Grewal, D., \& Mangleburg, T. (2000). Retail environment, self-congruity, and retail patronage: An integrative model and a research agenda. Journal of Business Research, 49(2), 127-138.

Sirgy, M.J., \&Su, C. (2000). Destination image, self-congruity, and travel behavior: Toward an integrative model. Journal of Travel Research, 38 (May), 340-352.

Smeijn, J., Van Riel, A.C.R., \&Ambrosini, A.B. (2004). Consumer evaluations of store brands: effects of store image and product attributes. Journal of Retailing and Consumer Services,11(4), 247-258.

Suebsaiaun, A., \&Pimolsathean, T. (2018). Thai home improvement retailer customer loyalty: A SEM analysis. Journal of International Studies, 11(4), 120-137.

Sung, E., \& Huddleston, P. (2017). Department vs. discount retail store patronage: effects of self-image congruence. Journal of Consumer Marketing. https://doi.org/10.1108/JCM-01-2016-1686.

The Jakarta Post (2017). BPOM takes action over Korean instant noodles containing pork - Food - The Jakarta Post. Retrieved January 28, 2018 fromhttp://www.thejakartapost.com/life/2017/06/19/bpom-takes-action-overkorean-instant-noodles-containing-pork.html

Tsai, W.C. (2001). Determinants and consequences of employee displayed positive emotions. Journal of Management, 27(4), 497-512.

Turley, L. W., \& Milliman, R. E. (2000). Atmospheric Effects on shopping behavior: A review of the experimental evidence. Journal of Business Research, 49, 193-211.

Urbancová, H., \& Hudáková, M. (2017). Benefits of employer brand and the supporting trends. Economics \& Sociology, 10(4), 41-50. 
Wang, J., \& Wang, X. (2012). Structural equation modeling: Application using Mplus. Higher Education Press. John Wiley \& Sons Ltd: United Kingdom

Zain, O. M., \& Saidu, M. B. (2016). The customers satisfaction on retailers' brand products: A study on selected areas in Klang Valley. Procedia Economics and Finance,35(35), 418-427.

Zeithaml, V. A. (1988). Consumer Perceptions of price, quality, and value: A means-end model and synthesis of evidence. Journal of Marketing, 52 (July), 2-22. 